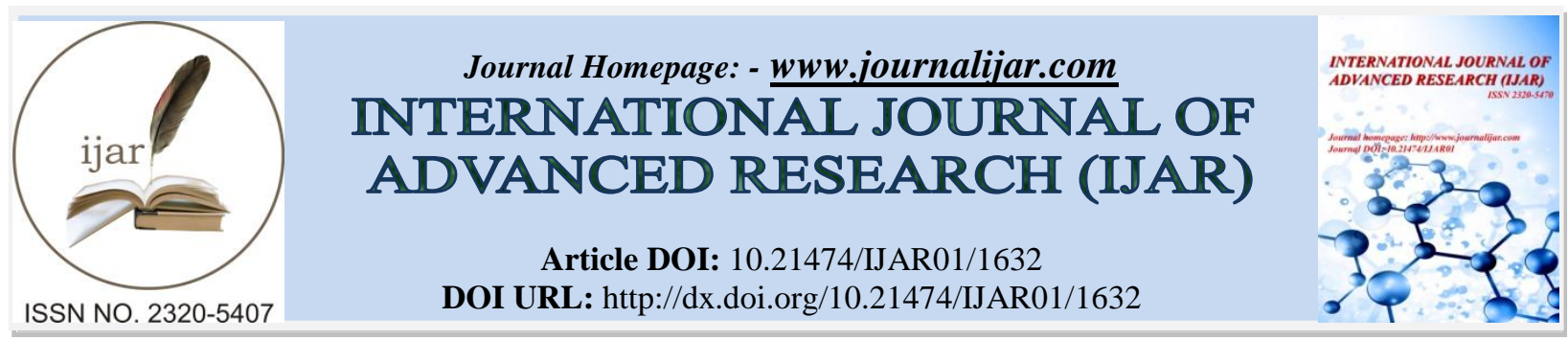

RESEARCH ARTICLE

\title{
BIOCHEMICAL IDENTIFICATION OF BACTERIA IN POLLUTED SOIL FROM MERDEKA VILLAGE, MERDEKA DISTRICT, KARO REGENCY.
}

\begin{abstract}
Lita Nasution $^{1 *}$, Edison Purba ${ }^{2}$, Erman Munir $^{3}$, Lisnawita $^{2}$, Ameilia Zuliyanti Siregar ${ }^{2 *}$ and Hasanuddin ${ }^{2}$.
1. Student in Doctoral Program of Environmental Resources Management, University Sumatera Utara, Indonesia 20155 and Lecture in Agrotechnology at Agricultural Faculty, Al-Azhar University, Indonesia 2015.

2. Lecture in Agroecotechnology at Agricultural Faculty, University Sumatera Utara, Indonesia 20155.

3. Lecture in Biology, FMIPA, University Sumatera Utara, Indonesia 20155.
\end{abstract}

\section{Manuscript Info}

Manuscript History

Received: 12 July 2016

Final Accepted: 22 August 2016

Published: September 2016

Key words:-

Biochemical, identification, dichloro diphenyl trichloroethane, bacteria, polluted soil

\begin{abstract}
Dichloro Diphenyl Trichloroethane residue are lipophiliec, they tent to accumulate in the fatty tissues of in gesting organisms along the food chain through consumption of agricultural products grown on contaminated soils. DDT residue in soil concern as their uptake can lead to accumulation in primary products. The removal residue of DDT from soil is therefore a priority. In this study the bacteria from DDT residue soil was isolated in top soil about $0-20 \mathrm{~cm}$ from Merdeka village, Merdeka district, Karo regency, North of Sumatra. DDT residue soil sample was extracted using QuEChERS method and determination of insecticide residue was carried out by gas chromatography mass spectrometry (GC-MS). One isolated bacteria identified for their activity in residue soil. Anaerob bacteria cultured in biological safety cabinet. Biochemical chart report from microbiology laboratory of H.Adam Malik hospital showed to have genus of Clostridium sp.

Copy Right, IJAR, 2016,. All rights reserved.
\end{abstract}

\section{Introduction:-}

Indonesia is rich for its natural resources. Agriculture has become the main source of living for the Indonesians. The land is cultivated to become land of agriculture such as rice field, plantation, fishery and horticulture. However, owing to the conventional system of land cultivation, the use of pesticide is still in high ratio. This is caused by a reality that the produce using pesticide is higher than that of using the organic.

Karo regency is located in North Sumatra. This region is the source of agricultural produce especially the horticultural and the use of chemical pesticide in this region is still widespread. Actually the use of pesticide is dangerous not only for the farmers but also for the environment. Pesticide also causes some health problems such as respiratory, reproduction, and womb disorder and pesticide also causes cancer and other dangerous diseases (Yuantari, 2011).

For the negative effects for the environment, pesticide can damage the fertility of the soil and the balance of the ecosystem. In the book 'Silent Spring' written by Rachel Carson, it is clearly pictured the negative effects of the long use of pesticide (Carson. 2002). Pesticide can cause disorder on micro flora ecology balance and on the change 
of soil micro flora (Hindersah, Rachman, Fitriatin, and Nursyamsi, 2013). Then pesticide can also cause total damage on various micro organism and even can get into the body of the fish and some other water livings. If nothing is done on this problem, there will be a great loss either for the humans or the farm soils and this will surely decrease the produce of the land. One of the substance in pesticide is DDT and this DDT is the result of chlorination process of DDE and DDD. The pathway is started from DDT to DDE, then becomes DDD or DDT and this is directly changed to DDD (Cruz., Gold, Gutirez, Monroy, and Favela, 1999).

DDT can spoil the fertility of the land as the micro organism of the land becomes lacked. The making of organic fertilizer by means of micro organism can be conducted as not all types of micro organism die in time of getting chemical substance from chemical pesticide.

Bases on the previous research result, it has already been proved that some micro organism could survive from the heavy metal composite of pesticide. Microbe can be used as a biodegradation (Verma, Jaiswal and Sagar, 2014). Microbe could also be used to degrade the chemical substance in the pesticide (Aislabie and Jones, 1995). The research results also show that microbe is the substance of biodegradation of DDT and other substance in the pesticide (Nadeau, Menn, Breen and Sayler, 1994; Baehki, and Khan, 1994; Yu., Bao, Liang and.Zeng, 2011; Santacruz., Bandala and Torres, 2010). So this research is done to find microorganism that can be used to be an agent of biodegradation that could survive in a chemical pesticide pollution condition.

\section{Materials And Method:-}

Method of taking soil sample:-

This research is conducted at Merdeka Village of Merdeka District, Karo Regency, North of Sumatra. The method of taking soil sample is conducted diagonally on 40 points of sample area with a depth of $0-20 \mathrm{cms}$.

\section{The residue test of soil sample:-}

DDT residue from the soil that has been isolated is extracted using the method of QuEChERS while the residue test of pesticide is done using the method of gas chromatography mass spectrometry (GC-MS).

\section{Bacteria Multiplying:-}

Bacteria multiplying is done using the method of Cookled Meat Medium (BBL and Difco, 2015). This method is frequently used to breed anaerob bacteria. The medium is by means of culturing on the media of egg yolk agar (EYA) for three days in incubation at the temperature of $37^{\circ} \mathrm{C}$ in anaerob condition of anaerob vessel with several modifications (Saraswati, Nagar, Kushwaha, , Kumar, Prasad and Agarawal, 2011).

\section{Bacteria Identification:-}

Bacteria identification is done by the cultural method and then the sample goes through biochemical test in the lab of H. Adam Malik Hospital.

\section{Finding and Analysis:-}

This research is initially conducted by taking some samples of soil from polluted area of DDT. Then isolation is done to get the kind of anerob bacteria using the method of Cooked Meat Medium. The result could be seen in Figure 1 .

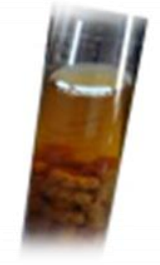

Figure 1: Cooked Meat Medium

After this, the multiplying of isolated bacteria is observed by microscope. Then the result from the research could be seen in Figure 2. 


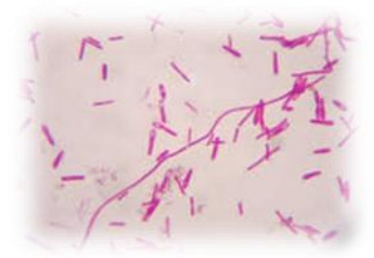

Figure 2: Bacteria from isolation

Based on the research result, the features of morphology are seen on the microscope appearing as spore in form of stem, pink and spread randomly on the surface of glass slide. The test result shows the gram positive. Then after the morphological test, the biochemical analysis is done to know the kind of bacteria that has been isolated. The result is presented in Table 1.

Table 1. Thebiochemical test result of isolated bacteria at Karo Regency

\begin{tabular}{|c|c|c|c|c|c|c|c|c|c|c|}
\hline \multicolumn{9}{|c|}{ Biochemical Details } \\
\hline 4 & dGAL & - & & & MORPH & - & & 62 & OPS & - \\
\hline 11 & dCEL & - & & 6 & ELLM & - & & 8 & ProA & - \\
\hline 28 & SAC & - & & 15 & APPA & - & & 20 & dMNE & - \\
\hline 39 & BGALi & - & & 33 & NAG & - & & 36 & URE & - \\
\hline 51 & MTE & - & & 42 & AGALi & - & & 44 & ARG & - \\
\hline 59 & PHOS & - & & 54 & BdFUC & - & & 56 & AMANi & - \\
\hline & GRAM & + & & 61 & dRIB2 & - & & 63 & AARAF & - \\
\hline 5 & LeuA & - & & & AERO & - & & 10 & PyrA & - \\
\hline 13 & TyrA & - & & 7 & PheA & - & & 22 & dMAL & - \\
\hline 30 & ARB & - & & 18 & Dglu & - & & 37 & BGURi & - \\
\hline 41 & AARA & - & & 34 & BGLUi & - & & 45 & PVATE & - \\
\hline 53 & ESC & - & & 43 & BMAN & - & & 57 & AIFUC & - \\
\hline 60 & IARA & - & & 55 & BNAGi & - & & 64 & dXYL & - \\
\hline
\end{tabular}

DDT is a chemical substance in pesticide and could be accumulated into a series of food (Kannan, Tanabe, Williams and Tatsukawa, 1994). DDT could be transformed by various types of bacteria on the aerob and anaerob condition (Cruz., Gold, Gutirez, Monroy, and Favela. 1999). On aerob condition DDT would be changed into DDE (1,1-bis(p-chlorophenyl)-2-dichloroethylene) then to 4- chloro benzoic acid, while on anaerob condition, DDT would be changed into DDD (1,1-dicloro-2,2-bis(p-chlorophenyl) ethane) then DDA (bis(p-chhloropenyl) acetic acid) and DBP (p,p-dichlorobenzophenone).

The result shows that there is a link between time duration $(0,6,10,14,16,20,28$ days) and process of fermentation (anaerob and aerob) on DDT (Aislabie and Jones, 1995). This also shows that the longer the time is, the more degradation is the DDT, DDE and DDD. The concentration of DDT gets up to the highest on anaerob condition while DDT and DDT will degrade the highest on the aerob condition.

Based on the biochemical test (Table 1) it is seen that the result is $98 \%$ of isolate bacteria including bacteria of Clostridium sp. This bacteria includes into the anaerob bacteria. Clostridium sp is a kind of bacteria that could survive on DDT polluted condition so that this bacteria could be made as biodegradation to enrich the previous research linked with biodegradation. Pseudomanasbacteria could be biodegradation for DDT (Santacruz, Bandala and Torres, 2010). The next research shows that the types of bacteria and fungi that could be used to degrade DDT are Escherichia coli, Enterobacter aerogenes, Enterobacter cloacae, Klebsiella pneumoniae, Pseudomonas aeruginosa, Pseudomonas putida, Bacillus species "Hydrogenomonas", and the fungi Saccharomyces cerevisiae, Phanerochaete chrysosporium, and Trichoderma viridae Science of the Total Environment 153: 29-49 (Lai, and Saxena, 1999; Alexander, 1985; Beunink and. Rehm, 1988; Aislabie, Richards and Boul, 1997; Kuhard, Johri, Singh and Ward, 2004).

Clostridium that have been found in this study, is a type of bacteria that can be isolated from soil contaminated with pesticides, where these bacteria are involved in the reduction cycle of metal (metal reduction) and biochemical metal 
(metal biogeochemical). While the study by (Aislabie, Richards and Boul, 1997) isolated the bacterial species is similar to C. aff. estertheticum and C. hydroxybenzoicum of Savannah River Site. SC metal contaminated Fe ${ }^{3+}$ in conduction reduction also succeeded in isolating and identifying of $C$. chromiireducens $\mathrm{sp}$. $\mathrm{Cr}^{6+}$ metal polluted soil and ground $\mathrm{Fe}^{6+}$ wetland. When compared with the research (Ankef, Sebastian,Andreas, Ralf, Tina, Andreas, 2015) who also succeeded in isolating Clostridium of copper metal contaminated soil at reducing conditions also shows the shape of the rod.

23. R.C..

Based on the results of biochemical analysis in Table 1 indicates that nearly all biochemical parameters showed a negative value (-) and included on gram (+). When compared with the study by (Brazier, Duerden, Hall, Salmon, Hood, Brett, Mclauchlin dan George, 2002). No one is on the same parameters urease parameters which each show a negative value (-), so that Clostridium spp. in this study with research by Brazier, Duerden, Hall, Salmon, Hood, Brett, Mclauchlin dan George (2002) using the species C. novyi A., C. perfringens, C. septicum,

C. botulium, C. tetani and $C$. sordellii / bifermentans show the similarities in the parameter urease (Kuhard, Johri, Singh and Ward, 2004). When compared with the results of the study (Chaturvedi and Shukla, 2015) showed the same results in Arabinose characteristics that indicate a negative value and the character of gram positive strain is the species $C$. perfringens, $C$. butrycum, C. sprogenes and C.tyrovutycum.

Effectiveness of microorganism to degrade the chemical substance is influenced by the a number of various factors and by this the capability of each microorganism will vary according to the condition. This is explained by Aislabie, Richards and Boul, 1997) that there are various influences in the process of biodegradation some of which are type and number of bacteria and some other environmental factors. Then temperature, oxygen concentration, the availability of nutrients in the soil and competition stage could influence the capability of microorganism in degrading DDT (Kuhard, Johri, Singh and Ward, 2004).

\section{Conclusions:-}

Based on the research result, it is stated that type of bacteria that has been isolated from the polluted soil caused by DDT is Clostridium sp.

\section{Acknowledgment:-}

Thanks to the H. Adam Malik Hospital and laboratory Microbiology, Faculty of Medicine University Sumatera Utara for their willingness to do biochemical analysis of isolated bacteria. Thank to Ministry of Research and Technology, Directorate General of Higher Education, Republic Indonesia for funding the research. Then thanks to all parties who have participated in this research, and each name could not be mentioned here.

\section{References:-}

1. M.C. Yuantari, 2011. Insecticides organochlorines impact on human health and the environment and abatement. Proceedings of the Seminary National.187-199.

2. R Carson. 2002. Silent Spring 40 th Anniversay edition. Houghton Mifflin Company. Boston. New York.

3. R. Hindersah, W. Rachman, W., Fitriatin, B.N and D. Nursyamsi. 2013. The population of microbes in the rhizosphere and Growth caisim (Brassica juncea) in Soil contaminated with insecticides Organochlorines after Konsoria microbial applications and Compost. Journal of Indonesian Nature 15 (2): 115-120.

4. A.C. Cruz., Gold, B., Gutirez, R.O., Monroy, H., and E. Favela. 1999. Anaerobic-aerobic biodegradation of DDT (Dichlorophenyl Trichlorethane) in Soils. Springer-Verlag. 63: 219-225.

5. J. P. Verma, D.K. Jaiswal and R.Sagar. 2014. Pesiticide relevance and their microbial degradation : a-stateof.art. Springer Science: 1-39.

1. 6 J. M. Aislabie and G.L. Jones. 1995. A review of bacterial degradation of pesticedes. Aust. J.Soil. Res.: 925-942.

6. L.J. Nadeau L. J., F-M Menn, A. Breen, and G.S. Sayler, G. S. 1994. Aerobic degradation of 1,1,1-trichloro-2,2bis (4-chloropheny1) ethane (DDT) by Alcaligenes eutrophus A5. Applied and Environmental Microbiology 60: $51-5$.

7. R.M. B. Baehki, and S.U. Khan. 1994. Degradation of atrazine, propazine, and simazine by Rhodococcus strain B-30. Journal of Agn'culture and Food Chemistry 42: 1237-1241.

8. H. Y.Yu., L.L. Bao., Y.Liang and E.Y.Zeng. 2011. Field Validation of Anaerobic Degradation Pathways for Dichlorodiphenyltrichloroethane (DDT) and 13 Metabolites in Marine Sediment Cores from China. Enviromental Science \& Technology 45: 5245-5252. 
9. G. Santacruz., E.R. Bandala and L.G. Torres. 2010. Chlorinated Pesticides (2,4-D and DDT) Biodegradation at High Concentrations Using Immobilized Pseudomonas Fluorescens. Journal of Environmental Science and Health Part B: 40:571-583.

10. BBL and Difco. 2015. Cooked Meat Medium. Quality Control Procedures.

11. P. Saraswati, Nagar, D.P., Kushwaha, K., Kumar, O., Prasad, G.B.K.S., and Agarawal, M.K. 2011. Isolation and PCR-Based Detection of Anaerobic Closgtridium bifermentans Isolated From Slaughterhouse Soil. Current Science (11): 101.

12. K. Kannan, S. Tanabe, R. J. Williams, and R. Tatsukawa. 1994. Persistant organochlorine residues in foodstuffs from Australia, Papua New Guinea and the Solomon Islands: contamination levels and dietary exposure. The Science of the Total Environment 153: 29-49.

13. R. Lai, and D. Saxena. 1999. Accumulation, metabolism and effects of organochlorine insecticides on microorganisms. Microbiological Reviews 46: 95-127.

14. M. Alexander. 1985. Microbial formation of environmental pollutants. Advanced Applied Microbiology 18:173.

15. J. Beunink, and H. Rehm, H. 1988. Synchronous anaerobic and aerobic degradation of DDT by an immobilized mixed culture system. Applied Microbiology and Biotechnology 29: 72-80.

16. J.M. Aislabie, N.K. Richards and H.L. Boul. 1997. Micobial degradation of DDT and its residues-a review. New Zealand Joornal of Agricultural Research. 40: 269-282.

17. R.C. Kuhard, A.K. Johri, A. Singh, A. and O.P Ward. 2004. Bioremediation of pesticide- contaminated soils. In: soil Biology, Applied bioremediation and phytoremediation (Eds: Singh, A. and Ward, O.P.) Springer Verlag, Heidelberg 1:35-54.

18. Ankef, F.H., Sebastian, B., Andreas, V., Ralf, K., Tina, L.B., Andreas, K. 2015. Clostridium Species as Metallic Copper-Forming Bacteria in Soil under Reducing Conditions. Geomicrobiology Journal. 32 : 130-139.

19. Brazier, J.S., Duerden, B.I., Hall, V., Salmon, J.E., Hood, J., Brett, M.M., Mclauchlin, J. dan George, R.C. 2002. Isolation and Identification of Clostridium Spp. from infections associated with injection of drugs: experiences of microbiological investigation team. J. Med. Microbiol.51: 985-989.

20. Chaturvedi, A. and Shukla, S., 2015. Occurance of clostridium species in dairy products and its associated health risk. Internasional Journal of Recent Scientific Research. 6: 2827-2829

21. J.M. Aislabie, N.K. Richards and H.L. Boul. 1997. Micobial degradation of DDT and its residues-a review. New Zealand Joornal of Agricultural Research. $40: 269-282$.

22. R.C. Kuhard, A.K. Johri, A. Singh, A. and O.P Ward, 2004. Bioremediation of pesticide- contaminated soils. In: soil Biology, Applied bioremediation and phytoremediation (Eds: Singh, A. and Ward, O.P.) Springer Verlag, Heidelberg. 1:35-54. 